\title{
Impact of Water Governance Regimes on Forage Characteristics and Soil Properties in Kajiado County, Kenya
}

\author{
Stanley Jawuoro ${ }^{1,}$, Erick Omollo ${ }^{1}$, Manei Naanyu ${ }^{1}$, Danny Simatele ${ }^{2}$, Consolata Muhindi ${ }^{3}$ \\ ${ }^{1}$ African Climate Leadership Program, University of Nairobi, Nairobi, Kenya \\ ${ }^{2}$ Department of Geography, Archaeology and Environmental Studies, University of the Witwatersrand, Johannesburg, South Africa \\ ${ }^{3}$ Jomo Kenyatta University of Agriculture and Technology (JKUAT), Nairobi, Kenya
}

Email address:

stanleyjawuoro@gmail.com (S. Jawuoro)

${ }^{*}$ Corresponding author

\section{To cite this article:}

Stanley Jawuoro, Erick Omollo, Manei Naanyu, Danny Simatele, Consolata Muhindi. Impact of Water Governance Regimes on Forage Characteristics and Soil Properties in Kajiado County, Kenya. International Journal of Atmospheric and Oceanic Sciences.

Vol. 3, No. 2, 2019, pp. 27-35. doi: 10.11648/j.ijaos.20190302.11

Received: July 22, 2019; Accepted: August 20, 2019; Published: December 20, 2019

\begin{abstract}
Water governance regimes have a profound effect on vegetation and soil attributes. This is because they directly impact on grazing patterns. Kenyan peri-urban drylands are grappling with climate change and variability, population spillover from neighboring towns and cities and land degradation that put strain on water resources. Water demand therefore outstrips supply. Sustainable water governance regimes are therefore a prerequisite for climate change resilience, building of adaptive capacities and reduction of climate induced vulnerabilities. This study sought to evaluate the impact of various water regimes on vegetation and soil attributes. Organizational and operational characteristics of diverse water governance regimes were studied and measured against respective vegetation and soil physio-chemical attributes. Soil and vegetation data was analyzed using one-way ANOVA on GenStat $15^{\text {th }}$ edition. The study revealed a shifting trend from traditional water resource management institutions to more formalized regimes. Both public and private water governance regimes and systems existed though most of these lacked proper documentation and clearly defined terms of engagement among relevant actors. These systems applied diverse water management approaches creating significance differences in plant species diversity $(\mathrm{p}<0.05$, $\mathrm{F}=0.565)$, richness $(\mathrm{p}<0.05, \mathrm{~F}=14.717)$, soil organic carbon $(\mathrm{p}<0.001, \mathrm{~F}=10.67), \mathrm{pH}(\mathrm{p}<0.05, \mathrm{~F}=4.84)$ and particle size distribution $(\mathrm{p}<0.05, \mathrm{~F}=5.72)$ because of varying extents of range access and use. This study concluded that there is need for integrating indigenous knowledge into modern water governance approaches for sustainable crop and livestock production systems. Both national and devolved governance structures should therefore invest in awareness and capacity building to enhance knowledge and skill transfer that would spur development of ecologically, socially and economically responsive systems aimed at augmenting climate resilience of current and emerging production systems and livelihoods.
\end{abstract}

Keywords: Water Governance Policy, Climate Resilience, Natural Resource Conservation

\section{Introduction}

African ecosystems will experience a drastic shift under future climate. Kenyan drylands are particularly vulnerable. As biomes shift, ecosystem functions may not adequately support traditional rural livelihood pathways such as pastoralism and rain-fed crop production $[1,2]$. Climate change is projected to alter the scope of survival for most plant species since there will be major changes in plant growth, survival, reproduction and distribution [3]. Rising temperatures in the country, and by extension East Africa, will limit the number of plant species available. These challenges are more complex in peri-urban drylands like Kajiado County, where anthropogenic drivers of plant community alterations are immense. Land use changes including expansion of agriculture and increase in more sedentary lifestyles as land acreage available per capita to support traditional mobile livestock production systems 
diminish and clearing of woodlands for real estate to accommodate the growing population have had led to reduced plant diversity, loss of soil productivity and a strain on water resources $[4,5]$. These impacts are expected to slow economic growth, make poverty alleviation more difficult, erode food security further and extrapolate existing and create new poverty pathways and traps especially in the rapidly urbanizing contexts like Kajiado. This region is increasingly becoming a climate change hotspot, where strong climate change signals (such as erratic rainfall and rising temperatures) is being compounded with a rising large pool of poor, vulnerable and economically, socially and politically marginalized groups [6].

Water governance has undergone massive shifts in recent years. There has been an increased effort geared towards institutionalization of water resource management regimes as opposed to the traditional, communal and customary natural resource governance regimes [7, 8]. In Kenya several changes have been brought about by the enactment and operationalization of the Water Act of 2002. Contrary to previous years where customary bodies formed the dominant decision making in issues related to water and pasture access and user rights especially in the drylands of Kenya, there is an attempt towards a clearly defined policy framework for water resource management which aims at enhancing adaptation to climate change and variability [9].

In order to achieve sustainability and enhance long-term adaptation and climate resilience, water governance systems must pursue ecosystem integrity. Water governance systems in arid and semi-arid lands should seek to promote sustainable livestock production in a manner that supports resilient and functional ecosystems for enhanced ecosystem services. These systems must leverage resilience in natural, restored or transformed ecosystems without negatively impacting on biodiversity or compromising the broader ecosystem integrity. They should aim at minimizing land degradation and enhancing sustainable land use practices. Livestock production is the main economic activity in Kajiado and water governance regimes must therefore provide for sustainable fodder production through improved forage species' diversity and productive soils that can support livestock grazing $[5,10]$. Besides, these governance regimes must support local communities in adapting to climate change and variability by augmenting socio-economic benefits. Further, these interventions must be designed, developed and implemented in an inclusive, participatory and transparent, considering the needs of and effects of climate change on marginalized groups such as women and youth and clearly defining capacity building pathways for communities. Capacity building processes are particularly pertinent because they align the local structures and contextualize local governance systems to sub-national, national and regional policy and landscape processes. For instance, in Kajiado County, water governance should be implemented as part of the Kenya National Adaptation plan (NAP) of 2016 and Kajiado County Integrated Development

\section{Plan (CIDP).}

There is need to formulate natural resource governance regimes using knowledge and science-based evidence that is duly informed by best researches and robust indigenous knowledge. This will provide a platform for use of credible climate scenarios that is locally relevant, support community learning networks and provide frameworks for robust monitoring and evaluation processes where trade-offs are assessed and flexible adjustments made based on the evaluation findings. Natural resource governance regimes should strive to promote transdisciplinary and multi-sectoral approaches to enhance collaboration, cooperation of multi-stakeholder groups to support cross-sectoral governance across scales.

Most water-based interventions have been haphazardly implemented in the drylands of East Africa with devastating ecological and socio-economic effects. Studies by the studies [11-13] revealed that water interventions had adverse effects on soils and vegetation in pastoral areas of Karamoja and Kajiado in Uganda and Kenya respectively. These studies concentrated on the impact of watering points on grazing patterns, but paid little attention to institutional dimensions needed for effective soil and vegetation management. This study therefore sought to understand the impact of water governance regimes on soil and vegetation as an effective way of evaluating whether or not they (water governance regimes) enhance climate change mitigation and adaptation and promote sustainable livestock production systems.

\section{Study Area}

The study was done in Kajiado County (Longitudes $36^{\circ} 5^{\prime \prime}$ and $37^{\circ} 5^{\prime \prime}$ East and Latitudes $10^{\circ} "$ and $\left.30^{\circ \prime \prime}\right)$. The altitude ranges from 1580 to 2460 metres above sea level. Kiserian is found in agro-ecological zone IV and is therefore a semi-arid region. Rainfall is bimodal in its distribution. The first rains, locally referred to as long rains are received from March to May while the short rains (second rains) fall between October and December [14]. The seasonal rainfall received within the County is between $300-1250 \mathrm{~mm}$. The minimum and maximum mean diurnal temperatures are $10{ }^{\circ} \mathrm{C}$ and $24{ }^{\circ} \mathrm{C}$ respectively. The $\mathrm{r} / \mathrm{ET}_{0}$ is $<0.65$ [15]. The main soil type in Kiserian is vertisols which are sticky when it's wet and form large cracks when it's dry [16, 17]. Acacia mellifera, Acacia tortilis, Acacia nubica, Acacia ancistroclada, Acacia nilotica, Commiphora riparia, Commiphora africana and Balanites aegyptiaca are the most common plant species [18].

The area has a population of about 202,651 people with a population growth rate of $4.5 \%$ and a life expectancy of 45 years [19]. The main land use and livelihood source is livestock rearing, although livelihoods have been diversified in order to capitalize on emerging social and economic opportunities and minimize environmental risks [5]. Formal employment, trade, cultivation and group ranching are replacing subsistence pastoralism in the area, especially among the traditionally nomadic Maasai community [4]. 


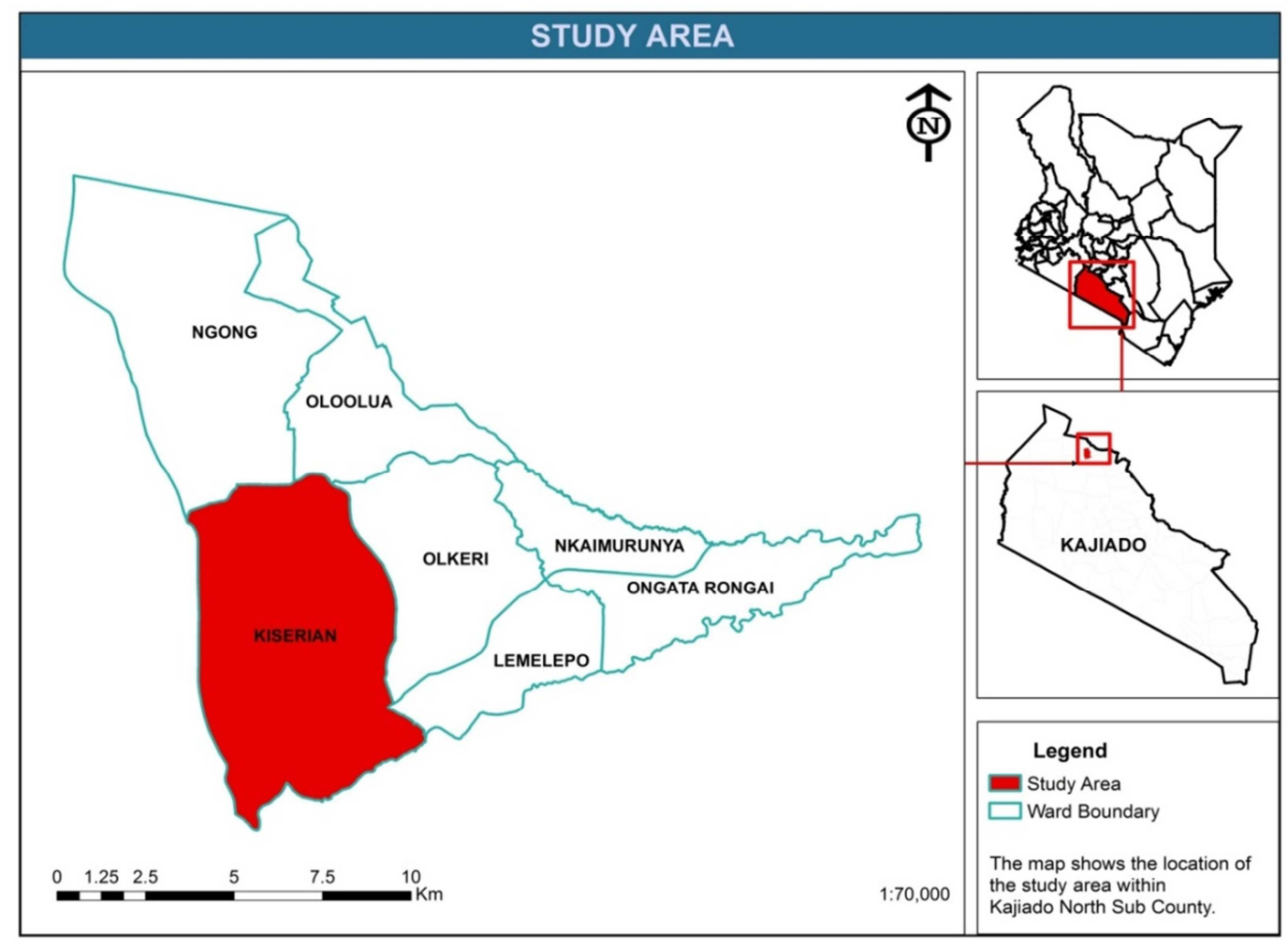

Figure 1. Map of Kajiado County Showing the study area.

\section{Methodology}

\subsection{Water Governance Data Collection}

Focus group discussions (FGDs), Key informant interviews and desk reviews were conducted to collect data on water governance regimes. A total of twelve FGDs were conducted for this study. Key informants were drawn mainly from the (Write in full before abbrev) WRUAs, private water owners such as ranchers, water service providers (WSPs) and line ministries especially from Kajiado County Government. These included the Water and Irrigation Ministry, Ministry of Agriculture, Livestock and Fisheries and Department of Forestry in the Ministry of Environment and Natural Resources. Parameters used to classify governance systems included availability of a viable and functional constitution, whether or not Annual General Meetings took place, how leaders were determined, term of office bearers, mode of water access, gender representation and whether the general membership could access official documents as part of accountability processes.

\subsection{Soil and Vegetation Sampling and Analysis}

Three watering points under different governance regimes were studied using a randomized block design. These included a dam, a borehole that used water troughs and a river. Both vegetation and soil samples were obtained from quadrats $\left(0.25 \mathrm{~m}^{2}\right)$ placed at an interval of $20 \mathrm{~m}$ along a 100 metre transect that was replicated four times in all the four cardinal directions (North, East, West and South). Species composition, diversity (Shannon Weiner), richness and evenness (Pielou) were determined using Krebs's formula [20] below;

$$
\left(\frac{n_{i}}{N}\right) \times 100
$$

Where, $n_{i}$ is the number of each species within a quadrat, while $\mathrm{N}$ is the total number of species within the same quadrat.

Species diversity was determined using Shannon Weiner's diversity index;

$$
\mathrm{H}^{\prime}=-\sum\left[\left(\frac{\mathrm{n}_{\mathrm{i}}}{\mathrm{N}}\right) \times \ln \left(\frac{\mathrm{n}_{\mathrm{i}}}{\mathrm{N}}\right)\right]
$$

Where; $\mathrm{n}_{\mathrm{i}}$ is the quantity of individuals of each species, $\mathrm{N}$ is the total number of individuals (or amount) for the site and $\mathrm{Ln}$ is the natural log of the number.

Species richness (S) was calculated as the total number of species per quadrat while Pielou evenness was calculated using as shown below;

$$
\mathrm{J}=\frac{\mathrm{H} \odot}{\ln (\mathrm{H} \odot)_{\max }}
$$

Where H' is the Shannon-Weiner's Diversity index for the quadrat and $\mathrm{HC}{ }_{\text {max }}$ is the natural log of species richness (S). Vegetation attributes (diversity, richness and evenness) are usually affected by climatic conditions and were therefore sampled during the long rains in the dry season.

Disturbed and undisturbed soil sampling was done for this study. Sampling disturbed soil was done by using $600 \mathrm{~cm}^{3}$ soil augers at a depth of $20 \mathrm{~cm}$. Four samples were obtained 
from all corners of the quadrats and mixed in a bucket forming a composite for each replication. These composites were further mixed and divided into four equal portions of $125 \mathrm{~g}$ each to form representative samples. This was repeated for all the replications until a $500 \mathrm{~g}$ sample was obtained. Soil samples were air dried at room temperature for seventy two hours and ground and sieved to eliminate stones, organic residues and plant material through a $2 \mathrm{~mm}$ wire mesh. The resultant soil samples were used for $\mathrm{pH}(5 \mathrm{~g})$ and soil texture determination $(50 \mathrm{~g})$. We analyzed soil particle size distribution (texture) using the hydrometer method and $\mathrm{pH}$ $\mathrm{H} 2 \mathrm{O}$ (ratio 1:2.5) by the $\mathrm{pH}$ meter method. Further sieving was done by use of a $0.5 \mathrm{~mm}$ sieve to enhance soil homogeneity since $<2 \mathrm{~g}$ of soil was required for soil organic carbon and nitrogen per cent determination [21-23]. WalkleyBlack method and Kjeldahl digestion method were used to determine soil organic carbon (SOC) and total nitrogen respectively [22, 24]. Undisturbed soil samples were sampled using steel core rings at the same depth of $20 \mathrm{~cm}$ and used for determination of soil bulk density, hydraulic conductivity and porosity determination. Bulk density was determined by the core method by dividing the mass of dry weight of soil (g) by the soil volume $\left(\mathrm{cm}^{3}\right)[25,26]$. Bulk density values obtained were used to calculate soil porosity using the formula by [27]; $1-\frac{\rho_{b}}{\rho_{s}}$ where, $\rho_{\mathrm{b}}$ is bulk density and $\rho_{\mathrm{s}}$ the particle density taken as $2.65 \mathrm{~g} \mathrm{cm-}^{3}$. Aggregate stability was determined by the wet sieving method gravimetric method was used to determine soil moisture. Saturated soil hydraulic conductivity was determined by the constant head permeameter using Darcy equation described by [28].

\section{Data Analysis}

Water governance regimes were summarized and discussed under various thematic areas of this study. Vegetation and soil analyses were performed using GenStat $15^{\text {th }}$ edition. One-way ANOVA was used to determine if there existed significant differences in vegetation and soil attributes among various water governance regimes. Mean comparison was done using Tukey's HSD test to determine if there were significant statistical differences between treatment pairs at $95 \%$ confidence interval.

\section{Results}

\subsection{Water Governance Regimes}

Water governance regimes observed under this study were categorized into four, according to how they were managed; those watering points under direct jurisdiction of Water Resource Users Associations (WRUAs) which are the custodians of water catchments under law those watering points that are managed by the Water Service Providers (WSBs) which are legally mandated to supply water and provide sanitation services, Public watering points owned by the Ministry of Water and managed by local community Water Management Committees (WMCs) and privately owned watering points including private boreholes, dams and watering troughs located in people's private homes and ranches. Data was collected and categorized broadly under dams, watering troughs and seasonal rivers [9]. Most rivers in the area are seasonal.

\subsection{Water Resource Users'Associations}

Water Resource Users' Associations are community based entities tasked with catchment conservation, settling disputes arising from water rights, access and use, among other functions at the local level $[8,9,13]$. This study analyzed the organizational and operational characteristics of Kiserian WRUA with a view to understand its role in instituting sustainable and responsive water governance regimes in the area. The WRUA had about 60 registered members, $75 \%$ of which were men. This could have probably been because most households were male-headed. It was therefore easier for them to make decisions concerning WRUA membership as opposed to their female counterparts who would also be deterred from joining and fully participating in the WRUAs owing to their reproductive roles and demand for time in performing household chores [29, 30]. Registration fees required for those joining the WRUA was a non- refundable, non-renewable Ksh. 500 (\$5). The executive committee of the WRUA consisted of the Chairperson, the treasurer and the secretary, all serving for a renewable two-year term. The WRUA had a constitution. An annual general meeting is supposed to be held every year. There was documentation of annual general meetings held in 2014 and 2018.

Notably, about $79 \%$ of WRUA members had participated in catchment conservation activities including creating awareness, river pegging, tree planting and de-siltation. However, these key roles have been hampered by lack of sufficient and consistent government funding, low literacy levels and lack of capacity building opportunities, a fact that has curtailed the ability of the WRUA to develop funding proposals to fund their activities and meaningfully engage in water resource conservation efforts. This could explain the reason for the degraded water catchment observed in the area, characterized by loss of biodiversity, pollution of water sources by alternative livelihood sources such as farming and slaughter houses and structures erected near rivers and springs in violation of National Environmental Management Authority (NEMA) regulations. With the rapid urbanization, a changing climate and growing population, the catchment situation may worsen.

\subsection{Water Service Providers}

Water service providers are public or private limited companies and non-governmental organizations mandated to supply water services under the Water Act of 2002. For instance, in Kajiado County, Oloolaiser Water Company built the Kiserian Dam in 2011. This dam supplies water to various parts of the County. The dam is under a twenty-hour security patrol and allows controlled community access and use for activities such as quarrying. Livestock does not 
directly drink from the dam since it has been fenced. Grazing is allowed within a distance from the dam to minimize pollution and reduce degradation. The company has planted trees around the dam.

\subsection{Water Management Committees (WMCs)}

These are committees that run public water points such as boreholes and water troughs. Access and use of these watering points are not restricted to humans, livestock and wildlife. Members of the public access water for free or at a fee depending on the terms stated by the government in consultation with the local communities.

\subsection{Privately Owned Watering Points}

These include watering points developed by individuals or groups to ease access to water for home consumption or livelihoods. In Kajiado County, several ranches, conservancies and homes water their livestock and wildlife using private watering points. Access and use of these points are mostly restricted to the owners, though the pastoral communities can be allowed limited access during severe droughts.

\subsection{Herbaceous Species Composition}

Table 1 shows the species composition (by relative densities) of various forage grasses at different watering points. Themeda triandra and Setaria holstii were the most abundant perennial grasses. Only three annual grasses were observed; Chloris pycnothrix, Eragrostis tuneifolia and Eriochloa fatmensis. Acacia-Themeda associations have been known to dominate a significant portion of Kajiado County $[13,18]$. Being one of the most palatable forage grasses, Themeda triandra is critical for sustaining livestock production in this region. Its proportion was however lowest around the troughs $(9.78 \%)$, an indication of high rates of degradation as a result of several factors; unrestricted access to water troughs, small size and large numbers of livestock and wildlife grazing in the region. Being that most troughs are owned by the government and hence available for uncontrolled use by the pastoralists, the ecosystem is likely to suffer from the "Tragedy of the Commons." This is because there are no legally instituted mechanisms regulating their access and use. In fact, further results revealed least number of grasses around the troughs (19) compared to dams (20) and seasonal rivers (21), an indication of poor range conditions.

Table 1. Relative densities of forage species at different watering points.

\begin{tabular}{lllll}
\hline \multirow{2}{*}{ Species } & \multirow{2}{*}{ Life form } & \multicolumn{3}{l}{ Relative Densities (\%) } \\
\cline { 3 - 5 } & & Dam & River & Trough \\
\hline Aristida adoensis & Perennial grass & 2.53 & 1.43 & 3.06 \\
Bothriochloa insculpta & Perennial grass & 7.28 & 4.94 & 7.16 \\
Brachiaria decumbens & Perennial grass & 0 & 0 & 2.69 \\
Brachiaria lacnatha & Perennial grass & 0 & 1.35 & 1.61 \\
Chloris pycnothrix & Annual Grass & 4.39 & 2.57 & 1.76 \\
Cymbopogon excavatus & Perennial grass & 0 & 2.43 & 2.12 \\
\hline
\end{tabular}

\begin{tabular}{lllll}
\hline \multirow{2}{*}{ Species } & \multirow{2}{*}{ Life form } & \multicolumn{3}{l}{ Relative Densities (\%) } \\
\cline { 3 - 5 } & & Dam & River & Trough \\
\hline Cymbopogon vallidus & Perennial grass & 1.75 & 1.94 & 0 \\
Cynodon dactylon & Perennial grass & 6.63 & 5.59 & 3.68 \\
Digitaria macroblephara & Perennial grass & 1.13 & 0 & 4.52 \\
Digitaria milanjiana & Perennial grass & 1.19 & 1.36 & 0 \\
Digitaria scalarum & Perennial grass & 2.32 & 4.12 & 10.28 \\
Eragrostis tuneifolia & Annual Grass & 7.41 & 13.24 & 6.12 \\
Eriochloa fatmensis & Annual Grass & 0.93 & 1.64 & 6.49 \\
Heteropogon contortus & Perennial grass & 2.49 & 0.98 & 0 \\
Hyperrhenia hirta & Perennial grass & 2.54 & 5.86 & 3.32 \\
Hyperrhenia lintonii & Perennial grass & 3.93 & 8.91 & 2.07 \\
Michrocloa kunthii & Perennial grass & 0.62 & 0.84 & 9.61 \\
Pennisetum mezianum & Perennial grass & 1.27 & 0 & 1.82 \\
Setaria holstii & Perennial grass & 25.05 & 13.66 & 20.37 \\
Setaria spacelata & Perennial grass & 3.03 & 3.89 & 3.54 \\
Setaria verticillata & Perennial grass & 4.31 & 8.12 & 0 \\
Sporobolus discosporus & Perennial grass & 0 & 1.16 & 0 \\
Sporobolus pyramidalis & Perennial grass & 2.56 & 1.12 & 0.53 \\
Themeda triandra & Perennial grass & 18.64 & 14.86 & 9.78 \\
N=24 & & 100 & 100 & 100 \\
\hline
\end{tabular}

\subsection{Species Diversity}

Figure 2 shows Shannon-Weiner's diversity index, species richness and Pielou's evenness at various watering points. Plant species diversity were significantly higher $(\mathrm{p}<0.05$, $\mathrm{F}=14.717)$, at the water dams $(1.50 \pm 0.11)$ compared to water troughs (1.19 \pm 0.20$)$ and seasonal rivers sampled (1.44 \pm 0.12$)$. Although Pielou's evenness did not significantly differ $(\mathrm{p}>0.05, \mathrm{~F}=.028)$ between watering points $(0.786 \pm 0.36$, $0.845 \pm 0.33$ and $0.856 \pm 0.32$ at the dams, seasonal rivers and water troughs respectively), species richness showed a significant difference $(\mathrm{p}<0.05, \quad \mathrm{~F}=0.565)$ between the seasonal river $(6.25 \pm 0.50)$, watering dams $(5.60 \pm 0.53)$ and the water troughs $(4.55 \pm 0.51)$. The observations could be attributed to higher concentration of grazing livestock and wildlife near the water troughs that led to high rates of trampling and overgrazing. As a result, plants were severely defoliated. Further, plant regeneration was significantly curtailed lowering plant species diversity. Under such conditions, only those species with high tolerance to grazing and small regeneration periods such as Cynodon dactylon and Eragrostis tuneifolia may exhibit resilience.

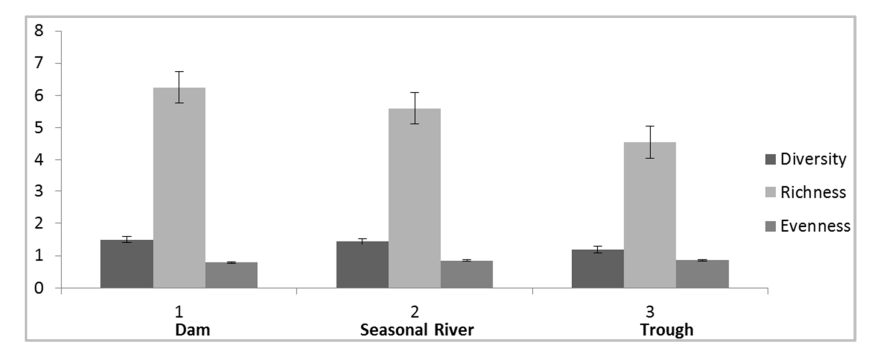

Figure 2 Plant species (Shannon Weiner) diversity, richness and Pielou evenness at various watering points in Kajiado County.

\subsection{Soil Physio-chemical Characteristics}

Soil physio-chemical properties at various watering points 
are shown in table 2. Saturated hydraulic conductivity, moisture content and soil aggregate stability did not significantly differ $(\mathrm{p}=0.072, \mathrm{~F}=2.91 ; \mathrm{P}=0.544, \mathrm{~F}=0.62$; $\mathrm{p}=0.073, \mathrm{~F}=2.92$ respectively) across the watering points. Hydraulic conductivity was lowest near the troughs, probably because of their small sizes that meant greater grazing animal and wildlife concentration per unit area in comparison to the dams and the seasonal rivers. This can also be attributed to greater compaction by grazing animals as observed in high bulk density $\left(1.11 \mathrm{~g} / \mathrm{cm}^{3}\right)$ and low soil porosity $(58.30 \%)$ recorded around the troughs relative to the dams' and seasonal rivers' bulk densities $\left(1.05 \mathrm{~g} / \mathrm{cm}^{3}\right.$ and $1.07 \mathrm{~g} / \mathrm{cm}^{3}$, respectively). This could be the reason for observed low per cent moisture content $(18.5 \%)$. The bulk densities and soil porosity were however significantly different $(p=0.319$, $\mathrm{F}=1.19 ; \mathrm{p}=0.24, \mathrm{~F}=1.52$ ) between the watering points. In general, these observations can be attributed to the nature of management regimes that governed their access and use. Dams were either private or governed by public Water Service Providers (WSBs) as provided for in the Water Act of 2002 [9]. A classic example was the Kiserian Dam built in 2011 and managed by the Oloolaiser Water and Sewerage Company. Access to dams was more restricted as local communities were allowed limited access. This might have helped in limiting the number of animals and humans accessing the dams at a point and hence led to reduced animal concentration around them.

Soil particle size distribution showed significant statistical difference in sand and clay content $(p=0.008, F=5.72$; $\mathrm{p}=0.001, \mathrm{~F}=10.80$ ), with per cent sand content being highest around the seasonal rivers $(62.82 \%)$ and lowest around the watering troughs $(57.72)$. In contrast, per cent clay content was highest around the watering troughs (36.01) and lowest around the water dams (29.60). There was however no significant difference in silt content $(\mathrm{p}=0.352, \mathrm{~F}=1.09)$ the dams and the seasonal rivers recording the highest $(7.70 \%)$ and the lowest (4.81) values, respectively. The main soil type in the area was Vertisols, and this explains the high clay content observed. High sand content symbolizes a great extent of degradation, a phenomenon common in Kenyan Arid and semi-arid lands as a result of overgrazing which exposes soils to high rates of evapotranspiration and water and wind erosion.

Total nitrogen and soil organic carbon were highest around the troughs ( 0.25 and 3.09 , respectively), a probable indication of greatest effect of accumulation of dung and urine brought about by concentration of grazing livestock and wildlife. This could also have been the cause of significantly lower $\mathrm{pH}(\mathrm{p}=0.016, \mathrm{~F}=4.84)$ observed around the troughs. Dung deposition leads to altered soil organic carbon, nitrogen and soil $\mathrm{pH}[11,31,32]$. Even though total nitrogen showed no significant difference $(p=0.549, F=0.61)$ between the watering points, soil organic carbon was significantly higher $(\mathrm{p}=0.001, \mathrm{~F}=10.67)$ around the troughs relative to the dams (2.49) and seasonal rivers (2.85). Animals were not restricted from accessing the troughs as opposed to the dams. Animals using the troughs at any given time were not controlled. This applied also to the seasonal rivers. The concentration of animals per unit area was however lower in the rivers compared to the troughs because animals could drink water from different points along the river.

Table 2. Soil physio-chemical properties at various watering points.

\begin{tabular}{|c|c|c|c|c|c|c|c|c|c|c|c|}
\hline Watering point & K_sat & $\% \mathrm{MC}$ & $\% \mathrm{SA}$ & BD $\left(\mathrm{g} / \mathrm{cm}^{3}\right)$ & Porosity & $\%$ Sand & $\%$ Clay & $\%$ Silt & $\%$ SOC & $\% \mathrm{~N}$ & Ph. \\
\hline Dam & $1.20^{\mathrm{a}}$ & $18.0^{\mathrm{a}}$ & $50.21^{\mathrm{a}}$ & $1.05 \mathrm{a}$ & $59.69^{\mathrm{a}}$ & $61.00^{\mathrm{ab}}$ & $29.60^{\mathrm{a}}$ & $7.70^{\mathrm{a}}$ & $2.49^{\mathrm{a}}$ & $0.21^{\mathrm{a}}$ & $6.02^{\mathrm{ab}}$ \\
\hline Seasonal River & $2.21^{\mathrm{a}}$ & $23.6^{\mathrm{a}}$ & $50.55^{\mathrm{a}}$ & $1.07 \mathrm{a}$ & $60.42^{\mathrm{a}}$ & $62.82^{\mathrm{b}}$ & $32.80^{\mathrm{ab}}$ & $4.81^{\mathrm{a}}$ & $2.85^{\mathrm{ab}}$ & $0.22^{\mathrm{a}}$ & $6.20^{\mathrm{b}}$ \\
\hline Trough & $0.13^{\mathrm{a}}$ & $18.5^{\mathrm{a}}$ & $48.57^{\mathrm{a}}$ & $1.11 \mathrm{a}$ & $58.30^{\mathrm{a}}$ & $57.72^{\mathrm{a}}$ & $36.01^{\mathrm{b}}$ & $6.28^{\mathrm{a}}$ & $3.09^{\mathrm{b}}$ & $0.25^{\mathrm{a}}$ & $5.95^{\mathrm{a}}$ \\
\hline S.E.D & 0.86 & 2.55 & 1.91 & 0.03 & 1.24 & 1.53 & 1.38 & 1.33 & 0.13 & 0.039 & 0.085 \\
\hline C.V $(\%)$ & 162.8 & 28.5 & 8.6 & 7.1 & 4.6 & 5.6 & 9.4 & 45.1 & 10.5 & 39.1 & 3.1 \\
\hline
\end{tabular}

Key: K_sat=Saturated Hydraulic conductivity, $\mathrm{MC}=$ Moisture Content, $\mathrm{SA}=$ Aggregate stability $\mathrm{BD}=$ bulk density, $\mathrm{SOC}=$ soil organic carbon, $\mathrm{N}=$ total nitrogen. Means with different letters in the same column show significant difference $(\mathrm{p}<0.05)$ between treatments.

\section{Discussion}

\subsection{Changing Trends in Water Resource Governance in Kajiado County}

This study revealed a shifting trend in how water resources are governed in Kajiado County. Previously, there were traditionally created institutions that controlled access and use of pasture and water resources. Currently, there is a massive difference in this scenario. The study observed an increased participation of both the local and national government in instituting water governance mechanisms. Formal entities such as the Water and Sewerage companies and non-governmental organizations are actively participating in generation and allocation of water resources. With livelihood shifts and emerging income diversification pathways, water resource management has also been greatly privatized. There is an emerging trend of individual ownership of boreholes, dams and water troughs. This study also observed a multi-stakeholder approach towards water resource governance; line ministries at both County and national levels, local communities through the Water Resource Users' Associations, law enforcement agencies such as the National Environmental Management Authority (NEMA). Kajiado County was a traditionally pastoral area. However, with the advent of land privatization, a significant proportion of these traditionally pastoral communities have shifted towards group ranching and conservancies [4, 14, 33]. The shift in water governance regimes and livelihood pathways can be attributed to several factors; Firstly, these communities are beginning to explore other very rewarding economic opportunities. The rise of conservancies in 
Kajiado has been triggered by potential benefits associated with eco-tourism. Besides, rapid urbanization and population spill-over from the nearby Nairobi City has led to shrinking of land available to support traditional nomadic lifestyles as more land is used for real estate. Thirdly, climate change has led to desertification and further degradation of these areas as low and erratic rainfall and high temperatures limit the production of pasture and water. Climate change and variability had led to an increase in livestock and zoonotic diseases through increased disease vectors. All these limit the productivity of livestock leading to reduced stocking rates, increased crop farming and sedenterized lifestyles. With the proliferation of these intersecting inhibitors to traditional pastoral production system (climate change, population pressure, land degradation etc.), there is an upsurge in water scarcity as water demand far outstrips supply. In order to mitigate these shortages, there is concerted effort from relevant stakeholders aimed at enhancing water resource conservation and governance for sustainable livelihoods.

\subsection{Impact of Water Governance Regimes on Fodder and Soils}

Water governance regimes have far reaching ecological implications. This is because these regimes affect species composition and soil physical and chemical properties by determining how watering points are accessed and used. Where access to water sources is unchecked, range condition is likely to deteriorate as overstocking stretches the range ecosystems beyond their carrying capacity. Watering points, like other piospheres such as animal kraals and salt licks, tend to concentrate grazing activity around them hence creating zones of differential impact around them [34, 35]. Overgrazing has been known to alter plant community dynamics through leaching of nutrients high compaction, increased defoliation and low regeneration rates and high soil organic carbon [36-38]. While conducting a study in Laikipia, Kenya, Alphayo reported low soil moisture, reduced soil aggregate stability, low soil hydraulic conductivity and altered plant composition in zones of continuous, high intensity grazing [39]. This corroborated a study by Wairore who observed high herbaceous diversity and above ground biomass in enclosures of Chepareria, West Pokot County, Kenya, further suggesting that controlled access to range resources could create less degraded ecosystems [40]. These observations agree with the findings of this study. Water management committees allowed uncontrolled access to a majority of watering troughs. This might have led to increased trampling and defoliation which led to reduced species diversity. Higher plant diversities were observed around dams where access by grazing livestock and wildlife was controlled. Range ecosystems are fragile in that they experience low and sporadic rainfall and high evapotranspiration. Consequently, proper management is critical for sustainable rangeland productivity and ecological well-being. Water governance regimes that apply restricted use of water resources will help in limiting length and intensity of grazing, allowing grass and other forage species to regenerate for continued nutrition of livestock and wildlife.

\subsection{Barriers and Opportunities in Water Resource Governance in Kajiado County}

There are bright prospects in regard to water resource governance systems in Kajiado and other arid and semi-arid areas of Africa. Among the pastoral households of Kajiado County, there however exist systemic and structural challenges to this realization. Low literacy levels among pastoral communities may hinder meaningful access to capacity building opportunities that enhance water resource conservation, information sharing and consequent access to quality and affordable water. As observed with the Water Resource Users' Associations studied, low literacies were a barrier towards training on funding proposal development. As a result, these WRUAs are unable to access funding opportunities outside what is provided by the Water Resource Authority (WRA). WRA is the chief funder of WRUAs [8, 13]. There are no clear stipulations on how WRA should fund WRUAs. A majority of the pastoral households are poor, hence unable to establish private boreholes and watering points and therefore depend on the ability of the catchments to produce sufficient water for daily use. This coupled with low-input, extensive and low-capital nature pastoral production system which is largely nature dependent further complicates the situation. One major hurdle towards the realization of sustainable water governance regimes is the enforcement of rules and regulations as stipulated in waterrelated laws. For instance, this study observed that there were high rates of pollutants emanating from slaughter houses. Sewage and other effluent were directly channeled into rivers and dams. There were also high concentrations of farming activities near rivers, contrary to the law. Yet, there is a laxity from the environmental enforcement agency (NEMA) and public health sectors in carrying out punitive actions against environmental offenders. This could probably be because of ineptitude and corruption within these systems. More importantly, however, is the lack of clear rules on how natural resources should be sustainably utilized, and possible consequences to investors and the general public should they violate the stipulations.

Opportunities exist for improved water resource governance in Kajiado and other Arid and semi-arid areas of Kenya in the future. The Constitution of Kenya 2010 classifies access to clean water as a basic human right [19]. This compels concerned authorities to formulate mechanisms aimed at providing water to residents in reasonable quantities and quality. If implemented alongside other existing water related laws and policies such as the Water Act of 2002 and the Integrated County Development Plan (CIDP), there is an increased likelihood of well planned and executed water related programmes and governance regimes. The constitution also brought about devolved governance systems, devolving key functions such as environmental conservation, agriculture and health. Devolution is a useful tool in creating localized, 
range site specific water governance regimes that ensure affordable access to quality water that meets the daily household demands and ensure ecosystem integrity.

\section{Conclusions and Recommendations}

Water governance regimes have a profound impact on fodder and soil characteristics. This study revealed significant effect of these regimes on species community composition, soil organic carbon and $\mathrm{pH}$, among other attributes, which have been directly and indirectly caused by diverse approaches to water resource access and use. Further, results showed a shift in trend from traditional informal water governance approaches to more institutionalized formations. In order to overcome barriers to sustainable water governance regimes (low literacy levels, lack of capacity building opportunities and lack of proper documentation), there is need for incorporation of indigenous knowledge pathways into water governance structural and systemic development in addition to a more coordinated approach among stakeholders at national, county and community levels as opposed to current sectarian approaches.

\section{Author Contributions}

Stanley Jawuoro designed the concept, collected, analyzed and interpreted data and drafted the manuscript. Erick Omollo, Manei Naanyu and Danny Simatele drafted the manuscript and contributed to study design. Consolata Muhindi is a governance Expert and helped in reviewing the document.

\section{Conflict of Interest}

Authors declare that there is no conflict of interest in this study.

\section{Acknowledgements}

We appreciate the International Development Research Centre (IDRC) for funding this research through the African Climate Change Leadership Program and the International Canopy of Conservation (I-CAN), the African Conservation Centre (ACC) and the University of Nairobi for their financial and technical support.

\section{References}

[1] Barrow, E., and Mogaka, H. (2007). Kenya's drylandswastelands or an undervalued national economic resource IUCN-The World Conservation Union, Nairobi.

[2] Huho, J. M., Ngaira, J. K., and Ogindo, H. O. (2011). Living with drought: the case of the Maasai pastoralists of northern Kenya. Educational Research, 2 (1), 779-789.

[3] Kreft, S., Eckstein, D., Junghans, L., Kerestan, C., \& Hagen, U. (2013). Global climate risk index 2014. Who suffers most from extreme weather events, 1 Á31.
[4] Kioko, J., and Okello, M. M. (2010). Land use cover and environmental changes in a semi-arid rangeland, Southern Kenya. Journal of Geography and Regional Planning, 3 (11), 322.

[5] Ogutu, J. O., Piepho, H. P., Said, M. Y., and Kifugo, S. C. (2014). Herbivore dynamics and range contraction in Kajiado County Kenya: climate and land use changes, population pressures, and governance, policy and human-wildlife conflicts. The Open Ecology Journal, 7 (1).

[6] Morton, J., \& Anderson, S. (2008). Climate Change and Agrarian Societies in Drylands. In Workshop on Social Dimensions of Climate Change. Washington DC: World Bank.

[7] Luwesi, C. (2010). Hydro-economic Inventory in a Changing Environment: An assessment of the efficiency of farming water demand under fluctuating rainfall regimes in semi-arid lands of South-East Kenya. Saarbrücken: Lambert Academic.

[8] Mathenge, J. M., Luwesi, C. N., Shisanya, C. A., Mahiri, I., Akombo, R. A., and Mutiso, M. N. (2014). Water security where governmental policies conflict with local practices: the roles of community water management systems in NgaciumaKinyaritha, Kenya. International Journal of Innovative Research and Development|| ISSN 2278-0211, 3 (5).

[9] K'Akumu, O. A. (2007). Toward effective governance of water services in Kenya. Water Policy, 9 (5), 529-543.

[10] Mganga, K. Z., Musimba, N. K. R., Nyariki, D. M., Nyangito, M. M., and Mwang'ombe, A. W. (2015). The choice of grass species to combat desertification in semi - arid Kenyan rangelands is greatly influenced by their forage value for livestock. Grass and Forage Science, 70 (1), 161-167.

[11] Egeru, A., Wasonga, O., Kyagulanyi, J., Majaliwa, G. M., MacOpiyo, L., and Mburu, J. (2014). Spatio-temporal dynamics of forage and land cover changes in Karamoja subregion, Uganda. Pastoralism, 4 (1), 1-21.

[12] Egeru, A., Wasonga, O., MacOpiyo, L., Mburu, J., Tabuti, J. R., and Majaliwa, M. G. (2015). Piospheric influence on forage species composition and abundance in semi-arid Karamoja sub-region, Uganda. Pastoralism, 5 (1), 1.

[13] Jawuoro, S. O., Koech, O. K., Karuku, G. N., \& Mbau, J. S. (2017). Organization And Performance Of Water Resource Users'associations In The Southern Rangelands Of Kenya. Tropical And Subtropical Agroecosystems, 20 (3), 401-411.

[14] Ogutu, J. O., Owen-Smith, N., Piepho, H. P., Said, M. Y., Kifugo, S., Reid, R. S., and Andanje, S. (2013). Changing wildlife populations in Nairobi National Park and adjoining Athi-Kaputiei Plains: collapse of the migratory wildebeest. Open Conservation Biology Journal, 7, 11-26.

[15] Middleton, N., and Thomas, D. (1997). World atlas of desertification (No. Ed. 2). Arnold, Hodder Headline, PLC.

[16] de Leeuw, P. N., Grandin, B. E., and Bekure, S. (1991). Introduction to the Kenyan rangelands and Kajiado district. Maasai herding: An analysis of the livestock production system of Maasai pastoralists in eastern Kajiado District, Kenya, 92-9053.

[17] Ombogo, M. O. (2013). The impact of climate variability on pastoralism: forage dynamics and trends in cattle population in Kajiado County, Kenya (Doctoral dissertation, University of Nairobi). 
[18] Bekure, S. (Ed.). (1991). Maasai herding: an analysis of the livestock production system of Maasai pastoralists in eastern Kajiado District, Kenya (Vol. 4). ILRI (aka ILCA and ILRAD).

[19] Morara, M. K., MacOpiyo, L., \& Kogi-Makau, W. (2014). Land use, land cover change in urban pastoral interface. A case of Kajiado County, Kenya. Journal of Geography and Regional planning, 7 (9), 192-202.

[20] Krebs, C. J. (1989). Ecological Methodology. Harper Collins Inc., New York.

[21] Day, P. R. (1965). Particle fractionation and particle-size analysis. Methods of soil analysis. Part 1. Physical and mineralogical properties, including statistics of measurement and sampling, (methodsofsoilana), 545-567.

[22] Brenner, J. M., and Mulvaney, C. S. (1982). Nitrogen total. Methods in Soil Analysis: Agronomy. Ed. CA Black, 595-624.

[23] Buresh, R. J., Austin, E. R., and Craswell, E. T. (1982). Analytical methods in $15 \mathrm{~N}$ research. Fertilizer Research, 3 (1), 37-62.S.

[24] Nelson, D. W., and Sommers, L. (1982). Total carbon, organic carbon, and organic matter. Methods of soil analysis. Part 2. Chemical and microbiological properties, (methodsofsoilan2), 539-579.

[25] Blake, G. R. (1965). Bulk density. Methods of soil analysis, 2, 375-377.

[26] McKenzie, N., Jacquier, D., Isbell, R., and Brown, K. (2004). Australian soils and landscapes: an illustrated compendium. CSIRO publishing.

[27] Flint, A. L., and Flint, L. E. (2002). 2.2 Particle Density. Methods of Soil Analysis: Part 4 Physical Methods, (methodsofsoilan4), 229-240.

[28] Reynolds, W. D., and Elrick, D. E. (2002). Constant head soil core (tank) method. Methods of soil analysis. Part, 4, 804-808.

[29] Coulibaly-Lingani, P., Savadogo, P., Tigabu, M., and Oden, P. C. (2011). Factors influencing people's participation in the forest management program in Burkina Faso, West Africa. Forest Policy and Economics, 13 (4), 292-302.

[30] Agevi, H., Wabusya, M., and Tsingalia, H. M. (2014). Community Forest Associations and Community-Based Organizations: Redesigning their Roles in Forest Management and Conservation in Kenya.
[31] Han, G., Hao, X., Zhao, M., Wang, M., Ellert, B. H., Willms, W., and Wang, M. (2008). Effect of grazing intensity on carbon and nitrogen in soil and vegetation in a meadow steppe in Inner Mongolia. Agriculture, Ecosystems and Environment, 125 (1), 21-32.

[32] Bell, A. L. W. (2010). Impacts of soil compaction by livestock on crop productivity-a modelling analysis. In Proceedings of the 19th World Congress of Soil Science: Soil solutions for a changing world, Brisbane, Australia, 1-6 August 2010. Symposium 3.1. 2 Farm system and environment impacts (pp. 117-120). International Union of Soil Sciences (IUSS), c/o Institut für Bodenforschung, Universität für Bodenkultur.

[33] Homewood, K. (2009). Policy and practice in Kenya rangelands: Impacts on livelihoods and wildlife. In Staying Maasai? (pp. 335-367). Springer New York.

[34] Smet, M., and Ward, D. (2006). Soil quality gradients around water-points under different management systems in a semiarid savanna, South Africa. Journal of Arid Environments, 64 (2), 251-269.

[35] Tarhouni, M., Salem, F. B., Belgacem, A. O., and Neffati, M. (2010). Acceptability of plant species along grazing gradients around watering points in Tunisian arid zone. FloraMorphology, Distribution, Functional Ecology of Plants, 205 (7), 454-461.

[36] Beukes, P. C., and Ellis, F. (2003). Soil and vegetation changes across a Succulent Karoo grazing gradient. African Journal of Range and Forage Science, 20 (1), 11-19.

[37] Al-Seekh, S. H., Mohammad, A. G., and Amro, Y. A. (2009). Effect of grazing on soil properties at southern part of West Bank Rangeland. Hebron University Research Journal, 4 (1), $35-53$.

[38] Shahriary, E., Palmer, M. W., Tongway, D. J., Azarnivand, H., Jafari, M., and Saravi, M. M. (2012). Plant species composition and soil characteristics around Iranian watering points. Journal of Arid Environments, 82, 106-114.

[39] Alphayo, L. (2015). Effects of holistic grazing management on soil physico-chemical properties and herbaceous vegetation production in Naibunga Conservancy, Laikipia County, Kenya (Doctoral dissertation, University of Nairobi).

[40] Wairore, J. N. (2015). Influence of enclosure management systems on rangeland rehabilitation in Chepareria, West Pokot County, Kenya (Doctoral dissertation, University of Nairobi). 